\title{
UJI CEMARAN Salmonella sp. DAN Staphylococcus aureus PADA DAGING KEBAB YANG DIJUAL DI JALAN DURIAN PEKANBARU
}

\author{
Titi Lasmini $^{1^{*}}$, Rika Yohana Sitorus ${ }^{2}$ \\ ${ }^{1}$ Akademi Kesehatan John Paul II Pekanbaru \\ ${ }^{2}$ Mahasiswi Akademi Kesehatan John Paul II Pekanbaru \\ *E-mail: lasmini.titi@gmail.com
}

\begin{abstract}
ABSTRAK
Kebab merupakan salah satu jenis makanan olahan yang menggunakan daging sebagai bahan utamanya. Daging merupakan bahan yang mengandung banyak nutrisi sehingga sangat mendukung untuk pertumbuhan berbagai mikroorganisme. Mengonsumsi daging yang terkontaminasi bakteri seperti Salmonella sp. dan Staphylococcus aureus akibat penanganan dan pengolahan daging yang kurang baik dapat menyebabkan penyakit (foodborne disease). Penelitian ini bertujuan untuk mengidentifikasi Salmonella sp. dan $S$. aureus pada daging kebab yang dijual di Jalan Durian Pekanbaru. Penelitian ini dimulai dengan menentukan Angka Lempeng Total (ALT) dilanjutkan isolasi pada media MSA dan SSA dan identifikasi dengan uji reaksi biokimia. Hasil penelitian menunjukkan bahwa nilai ALT dari 5 sampel daging kebab yang dijual di Jalan Durian Pekanbaru, 4 sampel melebihi batas maksimum cemaran mikroba yang diijinkan oleh SNI 7388:2009 (1 x 10 $\left.{ }^{5}\right)$. Uji biokimia menunjukkan semua sampel negatif $S$. aureus, dan ditemukan 1 sampel terkontaminasi Salmonella sp. (sampel A).
\end{abstract}

Kata kunci: Kebab, Meat, Salmonella, Staphylococcus aureus

\section{ABSTRACT}

Kebab is a type of processed food that uses meat as its main ingredient. Meat is a material that contains many nutrients, so it is very supportive for the growth of various microorganisms. Consumption of meat contaminated by bacteria such as Salmonella $\mathrm{sp}$. and Staphylococcus aureus due to poor handling and processing can cause disease (foodborne disease). This study aimed to identify Salmonella sp. and S. aureus in kebab meat sold at Jalan Durian Pekanbaru. This study commenced with a total plate count (TPC) followed by isolation on MSA and SSA media and identification with biochemical reaction test. The results showed that TPC value for 5 samples of kebab meat sold at Jalan Durian Pekanbaru, 4 samples exceeded the maximum allowable microbial contamination limits set by SNI $7388: 2009$ (1 $\left.x 10^{4} \mathrm{CFU} / \mathrm{g}\right)$. The biochemical tests revealed that all of the samples were negative for Staphylococcus aureus, and 1 sample (sample A) was found to be contaminated by Salmonella sp.

Keywords: Kebab, meat, Salmonella, Staphylococcus aureus 


\section{PENDAHULUAN}

Pangan adalah segala sesuatu yang berasal dari hewan atau tumbuhan yang diolah dengan cara yang sesuai sehingga dapat diserap oleh tubuh dan menjadi sumber energi (Sopandi dan Wardah, 2014). Pangan dapat mengandung banyak nutrient sehingga sangat mendukung bagi perkembangbiakan mikroba (Jarallah, Sahib dan Yasen, 2014). Undangundang Pangan no. 18 Tahun 2012 menyatakan bahwa untuk menjamin keamanan pangan maka setiap orang yang terlibat dalam rantai makanan wajib mengendalikan resiko bahaya pada pangan, baik yang berasal dari bahan, peralatan, sarana produksi, maupun perseorangan. Pangan tidak boleh mengandung cemaran mikroba melebihi batas maksimum yang telah ditetapkan dalam standar. Standar batas maksimum cemaran mikroba dalam pangan di Indonesia diatur dalam peraturan Kepala Badan POM nomor HK.00.06.1.52.4011 dan SNI 7388:2009.

Cemaran mikroba dalam pangan dapat menimbulkan kerusakan pada struktur pangan sehingga menyebabkan gangguan kesehatan bagi tubuh atau disebut dengan penyakit bawaan makanan (Foodborne disease) (Sopandi dan Wardah, 2014). Foodborne disease masih menjadi salah satu masalah kesehatan yang utama hingga saat ini di seluruh dunia. Kasus foodborne disease atau disebut juga sebagai keracunan makanan seringkali berasal dari konsumsi makanan siap saji yang terbuat dari daging seperti ham, sosis, burgers, kebab, daging kalengan, dan lain-lain (Agbodaze, et al., 2015; Kheyri et al., 2014).

Kebab merupakan salah satu jenis pangan jajanan yang menggunakan daging sebagai salah satu bahan utamanya. Para penjual biasanya menyimpan daging tersebut dalam jangka waktu yang cukup lama, sehingga mendukung pertumbuhan mikroba yang terdapat pada daging tersebut (Wulandari dan Zubaidah, 2016). Daging yang masih segar mengandung sedikit mikroba, tetapi bagian luar daging mudah mengalami kontaminasi baik selama proses pemotongan hewan, pengeluaran isi perut hewan, maupun penanganan daging setelah pemotongan. Sanitasi, pendinginan, dan penanganan daging yang tepat sangat diperlukan untuk meminimalkan kontaminasi dan menghambat aktivitas mikroba (Agbodaze, et al., 2005).
Proses penyiapan dan pemasakan daging kebab berpotensi menyebabkan daging tidak matang sempurna (undercooked) dan rentan kontaminasi baik dari daging mentahnya maupun dari bahan-bahan lain yang digunakan (Hillier, Krsteski, dan Rockliff, 2014). Beberapa jenis bakteri yang dapat menyebabkan kontaminasi pada daging mentah atau daging olahan seperti kebab adalah Salmonella sp., Campylobacter sp., Escherichia coli O157:H7 (Roels, et al., 1997), Staphylococcus dan Micrococcus (Ziino, Gurrera, dan Beninati, 2013).

Penelitian ini dilakukan dengan tujuan untuk mengidentifikasi Salmonella sp. dan Staphylococcus aureus pada daging kebab yang dijual di Jalan Durian Pekanbaru.

\section{TINJAUAN TEORI}

Beberapa jenis bakteri dapat tumbuh serta berkembang dalam bahan pangan sehingga bahan pangan menjadi rusak. Bakteri yang mencemari bahan pangan seperti daging, dapat berasal dari luar seperti udara, air atau pada saat penyembelihan tidak menggunakan perkakas yang bebas dari kontaminasi (Sopandi dan Wardah, 2014). Daging yang disimpan dalam jangka waktu yang cukup lama juga menjadi salah satu faktor yang meningkatkan risiko terjadinya kerusakan pangan (Wulandari dan Zubaidah, 2016). Konsumsi makanan yang mengandung mikroba pathogen dapat menyebabkan penyakit (foodborne disease).

Beberapa jenis bakteri yang dapat menyebabkan foodborne disease atau lebih dikenal dengan keracunan makanan adalah Bacillus cereus, Campylobacter, Clostridium botulinum, C. perfringens, E. coli, Listeria monocytogenes, Salmonella, Shigella, Staphylococcus aureus, Vibrio, dan Listeria (Adams dan Moss, 2008). Bakteri yang paling umum menyebabkan kontaminasi pada makanan yang berasal dari hewan adalah Salmonella sp. (Kheyri, et al., 2014). Bakteri Salmonella dapat menyebabkan salmonellosis, demam tifoid, atau gastroenteritis jika masuk kedalam tubuh dalam jumlah berlebih (Mahon, Lehman, dan Manuselis, 2015).

Bakteri $S$. aureus adalah flora normal pada kulit manusia, tetapi bakteri ini dapat menghasilkan enterotoksin yang bersifat tahan panas sehingga dapat menyebabkan keracunan makanan (Mahon, Lehman, dan Manuselis 
2015). Kheyri et al. (2014) menyatakan bahwa $S$. aureus adalah salah satu bakteri pathogen pada produk daging khususnya daging yang telah mengalami kontak dengan tangan secara langsung.

Selain disebabkan oleh bakteri, keracunan makanan juga dapat disebabkan oleh kapang penghasil mikotoksin seperti Aspergillus flavus, Fusarium, dan Penicillium (Hocking et al., 2006), Protozoa seperti Entamoeba histolica atau virus seperti virus Hepatitis A dan E, gastroenteritis virus, bahkan virus polio (genus Enterovirus) (Adams dan Moss, 2008).

\section{METODE PENELITIAN}

\section{Jenis dan Desain Penelitian}

Penelitian ini bersifat eksperimental laboratory secara invitro, yaitu dengan menumbuhkan bakteri dari sampel daging kebab yang dijual di Jalan Durian Pekanbaru pada medium kultur selektif MSA dan SSA, kemudian dilanjutkan dengan uji reaksi biokimia untuk mengidentifikasi jenis bakteri.

\section{Waktu Dan Tempat Penelitian}

Penelitian ini dilaksanakan pada bulan Juni sampai Agustus 2017, di Laboratorium Bakteriologi Akademi Kesehatan John Paul II Pekanbaru.

\section{Populasi dan Sampel penelitian}

Populasi yang digunakan dalam penelitian ini yaitu daging kebab yang dijual di Jalan Durian Pekanbaru. Sampel yang digunakan adalah daging kebab yang diambil dari 5 pedagang berbeda yang berjualan di Jalan Durian Pekanbaru.

\footnotetext{
Alat dan Bahan

-alat yang digunakan dalam penelitian ini adalah alat-alat gelas, Blender, Colony counter, Jarum Ose, Inkubator, mikropipet, mikroskop, Otoklaf, Oven, spatula, timbangan digital. Adapun bahan yang digunakan dalam penelitian ini adalah Daging Kebab, garam fisiologis $0,9 \%, 1$ set pewarnaan gram, reagen Kovac's, reagen $\mathrm{H}_{2} \mathrm{O}_{2}$, Bromothymol blue, minyak imersi, Media Pertumbuhan bakteri (Nutrient Agar, Mannitol Salt Agar, Salmonella Shigella Agar), media reaksi biokimia (Triple Sugar Iron Agar, Sulfur Indol Motility agar, Simmon Citrate agar, buffered peptone water), dan karbohidrat (glukosa,
}

laktosa, Mannitol, maltosa, sukrosa).

\section{Prosedur Kerja}

Cuci tangan menurut WHO 2009 dan gunakan APD (alat pelindung diri) sebelum bekerja.

\section{Persiapan Sampel}

Sampel diambil dari pedagang, dan dibawa ke laboratorium secara aseptis.

1. Sampel daging kebab ditimbang sebanyak 25 gr secara aseptis, lalu dimasukkan kedalam blender.

2. Aquadest steril ditambahkan kedalam blender sebanyak $225 \mathrm{~mL}$ (pengenceran $\left.10^{-1}\right)$.

3. Sampel diblender selama \pm 2 menit, kemudian diendapkan selama 15 menit.

4. Homogenat dipipet $1 \mathrm{~mL}$ dan dimasukkan kedalam tabung reaksi yang berisi aquadest steril sebanyak $9 \mathrm{~mL}\left(10^{-2}\right)$.

5. Pengenceran dilakukan sampai diperoleh pengenceran $10^{-6}$

\section{Angka Lempeng Total (ALT)}

1. Sampel dari masing-masing pengenceran diambil sebanyak $1 \mathrm{~mL}$ kemudian dimasukkan ke dalam cawan petri steril.

2. Media Nutrien agar yang masih dalam keadaan cair pada suhu $\pm 45^{\circ} \mathrm{C}$ dituang ke dalam cawan petri yang sudah berisi larutan sampel.

3. Cawan petri digoyang searah jarum jam sehingga larutan tercampur secara merata, kemudian dibiarkan memadat.

4. Lakukan langkah kerja no 1-3 sebanyak 3 kali pengulangan.

5. Semua cawan petri diinkubasi dengan suhu $37^{\circ} \mathrm{C}$ selama $2 \times 24$ jam

6. Jumlah koloni yang tumbuh dihitung menggunakan colony counter.

\section{Isolasi dan purifikasi Bakteri Pada Media Selektif}

1. Sampel dari masing-masing pengenceran dipipet sebanyak $1 \mathrm{~mL}$, lalu dituangkan kedalam cawan petri kemudian dituangkan media SSA dan MSA dan dihomogenkan

2. Semua cawan petri diinkubasi pada suhu $37^{\circ} \mathrm{C}$ selama $2 \times 24 \mathrm{jam}$.

3. Koloni yang diduga sebagai Salmonella dan $S$. aureus diambil dengan ose kemudian diinokulasikan pada media SSA dan MSA yang baru hingga diperoleh koloni tunggal. 
4. Koloni tunggal digoreskan pada media NA steril dan disimpan sebagai kultur stok untuk diuji lebih lanjut.

\section{Identifikasi Bakteri}

1. Koloni bakteri murni yang berasal dari kultur 24 jam diambil dengan ose dan dilakukan pewarnaan Gram dan Uji katalase dengan meneteskan reagen $\mathrm{H}_{2} \mathrm{O}_{2}$ dan diamati terbentuknya gelembung gas.

2. Dilakukan penanaman pada media reaksi biokimia TSIA (ditusuk dan digores), media SIM (ditusuk), media Simmon Citrate (digores), dan media Gula-gula (disuspensikan).

3. Seluruh media uji yang sudah diinokulasi diinkubasi pada suhu $37^{\circ} \mathrm{C}$ selama 24 jam lalu diamati ada tidanya perubahan warna media.

4. Media SIM ditetesi dengan reagen Kovac's untuk mendeteksi adanya indol (Leboffe dan Pierce, 2011).

\section{Pengolahan Data}

Jumlah koloni yang tumbuh pada setiap cawan ALT dihitung sehingga diperoleh data berupa jumlah koloni bakteri per gram sampel $(\mathrm{CFU} / \mathrm{g})$. Penentuan ada tidaknya bakteri Salmonella sp. dan S. aureus pada daging kebab diperoleh dengan membandingkan data yang diperoleh dari pengamatan makroskopis, mikroskopis, dan uji reaksi biokimia bakteri uji terhadap data yang terdapat di literatur.

\section{Analisis Data}

Data yang diperoleh dianalisisa secara kualitatif dan kuantitatif yaitu dengan mendeskripsikan hasil pengamatan mikroskopis, makroskopis, serta uji biokimia. Identifikasi bakteri dilakukan mengacu pada buku Bergey's Manual Determinative of Bacteriology (Holt, et al., 2000)

\section{HASIL DAN PEMBAHASAN}

\section{Hasil}

\section{Angka Lempeng Total (ALT)}

Hasil penghitungan jumlah koloni bakteri dari sampel daging kebab yang dibeli dari Jalan Durian Pekanbaru ditemukan hanya 1 sampel yang memenuhi standar batas maksimum cemaran mikroba yaitu sampel A. Tabel 1 menunjukkan nilai Angka Lempeng Total yang diperoleh dari rata-rata jumlah koloni pada cawan duplo.

Tabel 1. Nilai Angka Lempeng Total pada 5 Sampel Daging Kebab

\begin{tabular}{ccccc}
\hline Nomor & Sampel & $\begin{array}{c}\text { Angka Lempeng Total } \\
(\text { CFU/gram })\end{array}$ & $\begin{array}{c}\text { Standar Nasional } \\
\text { Indonesia (SNI) } \\
7388: 2009\end{array}$ & Keterangan \\
\hline 1 & A & $4,49 \times 10^{4}$ & $\begin{array}{c}1,0 \times 10^{5} \\
\text { CFU/gram } \\
1,0 \times 10^{5}\end{array}$ & MS \\
2 & B & $2,18 \times 10^{5}$ & CFU/gram & TMS \\
3 & C & $1,77 \times 10^{5}$ & $\begin{array}{c}\text { CFU/gram } \\
1,0 \times 10^{5}\end{array}$ & TMS \\
4 & D & $9,27 \times 10^{6}$ & CFU /gram & TMS \\
& & & $1,0 \times 10^{5}$ & TMS \\
\hline
\end{tabular}

*Ket: MS = Memenuhi Syarat; TMS $=$ Tidak Memenuhi Syarat

\section{Seleksi koloni bakteri Salmonella dan $S$. aureus}

Hasil Isolasi dari 5 sampel pada media selektif SSA diperoleh 1 sampel yaitu sampel A yang menunjukkan adanya pertumbuhan koloni yang diduga merupakan Salmonella yaitu koloni tidak berwarna dengan warna hitam dibagian tengah koloni, tepian halus, elevasi cembung, densitas translucent (isolat SL 1) (Tabel 2).
Hasil isolasi pada media MSA diperoleh 4 sampel positif ditemukan adanya koloni yang diduga Staphylococcus aureus yaitu sampel A, B, D, dan E. Keempat sampel tersebut menunjukkan adanya pertumbuhan bakteri yang membentuk koloni berwarna kuning, tepian halus, elevasi cembung, dan densitas opaque. Bakteri ini mampu memfermentasi Mannitol pada media MSA ditandai dengan perubahan warna dari merah menjadi kuning (isolat ST1, ST2, ST3, ST4) (Tabel 2). 
Isolasi bakteri dari sampel $\mathrm{C}$ tidak ditemukan adanya pertumbuhan koloni dengan karakteristik Salmonella pada SSA, serta tidak ditemukan koloni dengan karakteristik koloni Staphylococcus aureus pada media MSA.

\section{Reaksi biokimia 5 isolat bakteri}

Uji reaksi biokimia merupakan uji yang digunakan untuk menentukan genus atau spesies bakteri. Penentuan genus atau spesies bakteri dilakukan dengan mengamati adanya perubahan warna, dan atau pembentukan gas pada media uji, atau reaksi yang terjadi ketika bakteri diberi perlakuan dengan reagen tertentu.

Tabel 2. Pertumbuhan Koloni Bakteri pada Medium selektif

\begin{tabular}{|c|c|c|c|c|c|}
\hline \multirow{2}{*}{ Uji } & \multicolumn{5}{|c|}{ Isolat bakteri } \\
\hline & SL1 & ST1 & ST2 & ST3 & ST4 \\
\hline \multicolumn{6}{|l|}{ Morfologi koloni } \\
\hline - Bentuk & Bulau & Bulat & Bulat & Bulat & Bulat \\
\hline - Warna & $\begin{array}{l}\text { Tidak } \\
\text { berwarna } \\
\text { dengan } \\
\text { titik hitam } \\
\text { ditengah }\end{array}$ & Kuning & Kuning & Kuning & Kuning \\
\hline - Tepian & Halus & Halus & Halus & Halus & Halus \\
\hline - $\quad$ elevasi & Cembung & Cembung & Cembung & Cembung & Cembung \\
\hline - Densitas & Translucent & Opaque & Opaque & Opaque & Opaque \\
\hline Morfologi sel & Batang & Kokus & Kokus & Kokus & Kokus \\
\hline Gram & negatif & positif & positif & positif & positif \\
\hline Katalase & + & + & + & + & + \\
\hline \multicolumn{6}{|l|}{ TSIA } \\
\hline - $\quad$ Fermentasi gula & $\mathrm{A} / \mathrm{A}$ & $\mathrm{K} / \mathrm{K}$ & $\mathrm{K} / \mathrm{K}$ & $\mathrm{K} / \mathrm{K}$ & $\mathrm{K} / \mathrm{K}$ \\
\hline - $\quad$ Sulfur & - & - & - & - & - \\
\hline - Gas & + & - & - & - & - \\
\hline \multicolumn{6}{|l|}{ SIM } \\
\hline - $\quad$ Sulfur & + & - & - & - & - \\
\hline - Indol & - & - & - & - & - \\
\hline - Motility & + & + & + & - & - \\
\hline Simon Citrate & - & - & - & - & - \\
\hline \multicolumn{6}{|l|}{ Fermentasi Karbon } \\
\hline - $\quad$ Glukosa & + & - & - & - & - \\
\hline - Laktosa & - & - & - & - & - \\
\hline - Mannitol & + & - & - & - & - \\
\hline - Maltosa & + & - & - & - & - \\
\hline - $\quad$ Sukrosa & - & - & - & - & - \\
\hline
\end{tabular}

Isolat SL1 yang diperoleh dari sampel A memiliki ciri koloni yang menyerupai koloni Salmonella sp. pada media SSA yaitu koloni tidak berwarna dengan titik hitam ditengah koloni. Menurut Leboffe dan Pierce (2011) Salmonella mampu membentuk $\mathrm{H}_{2} \mathrm{~S}$ sebagai hasil pemecahan asam amino yang mengandung unsur belerang (sulfur) seperti 
lisin dan metionin. $\mathrm{H}_{2} \mathrm{~S}$ yang dihasilkan akan bereaksi dengan ion $\mathrm{fe}^{2+}$ yang terkandung dalam media agar sehingga membentuk endapan hitam.

Hasil pewarnaan gram dan uji reaksi biokimia terhadap isolat SL1 menunjukkan bahwa isolat tersebut merupakan bakteri gram negatif berbentuk batang pendek, katalase positif, mampu memfermentasi glukosa, sukrosa, dan laktosa pada media TSIA, menghasilkan $\mathrm{H}_{2} \mathrm{~S}$, motil dan tidak menggunakan sitrat sebagai sumber karbon tunggalnya. Hasil uji terhadap isolat SL1 memiliki persamaan dengan karakter bakteri Salmonella yang terdapat dalam buku Bergey's Manual Determinative Of Bacteriology, sehingga dapat dinyatakan bahwa isolat SL1 adalah bakteri Salmonella sp.

Empat dari 5 sampel (sampel A, B, D, dan E) yang diinokulasi pada media MSA menunjukkan adanya pertumbuhan koloni bakteri yang menyerupai koloni Staphylococcus aureus. Menurut Mahon, Lehman, dan Manuselis (2015), Staphylococcus aureus tumbuh membentuk koloni yang mampu menghasilkan pigmen kuning hingga jingga dan mampu menghasilkan produk sampingan yang bersifat asam sehingga menurunkan $\mathrm{pH}$ pada media dan menggubah warna indicator $\mathrm{pH}$ dari merah menjadi kuning. Isolat ST1, ST2, ST3, dan ST4 memiliki persamaan ciri koloni dengan $S$. aureus.

Hasil pewarnaan gram menunjukkan bahwa isolat ST1, ST2, ST3, dan ST4, merupakan bakteri berbentuk coccus gram positif dengan susunan bergerombol seperti buah anggur. Menurut Holt, et al. (2000), bakteri $S$. aureus memiliki ciri-ciri kokus gram positif bergerombol seperti anggur dan brsifat non-motil. $S$. aureus mampu memfermentasi gula-gula pada media TSIA (A/A), menggunakan sitrat sebagai sumber karbon, dan memfermentasikan media gula-gula (glukosa, laktosa, Mannitol, maltosa, laktosa.

Uji reaksi biokimia terhadap 4 isolat yang diduga $S$. aureus menunjukkan bahwa semua isolat tidak mampu memfermentasikan gulagula, pada media TSIA $(\mathrm{K} / \mathrm{K})$ serta tidak menghasilkan sulfur dan indol, tidak menggunakan sitrat sebagai sumber karbon dan tidak memfermentasikan gula-gula (glukosa, laktosa, Mannitol, maltosa, dan sukrosa). Hasil uji tersebut tidak sesuai dengan karakteristik $S$. aureus tetapi mirip dengan karakteristik bakteri dari genus Micrococcus yang terdapat dalam buku Bergey's Manual Determinative Of Bacteriology.

\section{Pembahasan}

SNI 7388 : 2009 mengenai batas maksimum cemaran mikroba pada pangan menyatakan bahwa nilai ALT untuk produk daging dan olahannya adalah 1 x $10^{5}$ CFU/gram. Berdasarkan batas tersebut dapat dinyatakan bahwa hanya 1 sampel yaitu sampel A yang memenuhi syarat dan layak untuk dikonsumsi. Empat sampel daging Kebab yaitu sampel B, C, D, dan E mengandung mikroba melebihi batas maksimum cemaran yang diijinkan dan tidak layak untuk dikonsumsi. Tingginya jumlah cemaran di dalam daging kebab menunjukkan bahwa pedagang kurang memperhatikan sanitasi makanan yang dikelolanya dan cara memasak daging yang kurang tepat, sehingga mikroorganisme yang terdapat pada daging kebab tidak musnah secara sempurna.

Pencemaran makanan oleh mikroorganisme tidak terlepas dari alur atau proses pengelolaan makanan mulai dari pemilihan bahan makanan, penyimpanan makanan, pengangkutan, dan penyajian makanan itu sendiri (Agbodaze, et al., 2005). Menurut Depkes RI tahun 2004, keenam proses tersebut dikenal dengan prinsip higiene sanitasi makanan. Kualitas bahan makanan yang baik dapat dilihat melalui ciri-ciri fisik dan mutunya seperti bentuk, warna, kesegaran, bau, dan lainnya. Penyimpanan bahan makanan saperti daging burger atau kebab harus disimpan pada suhu tertentu menurut lama penggunaan. Apabila daging tersebut digunakan dalam 3 hari atau kurang, maka suhu penyimpanan harus $-5^{\circ} \mathrm{C}$ sampai $0^{\circ} \mathrm{C}$.

Menurut penelitian Ginting, et al. (2013) Faktor yang paling banyak tidak dipenuhi oleh pedagang yaitu pedagang tidak langsung mencuci peralatan yang sudah dipakai, seperti alat memasak dan tempat penggorengan. Alatalat tersebut akan dicuci ketika selesai berjualan dengan alasan keterbatasan sumber air pada tempat berjualan. Peralatan juga tidak dilap atau dikeringkan, hanya dibiarkan hingga air mengering sendiri, dan diletakkan pada tempat yang tidak tertutup sehingga beresiko terjadi pencemaran.

Sarana penjualan yang baik dan lengkap harus memenuhi persyaratan yaitu kontruksi sarana penjaja mudah dibersihkan, tersedia 
tempat untuk penyimpanan bahan makanan, tersedia untuk tempat makanan yang sudah siap saji, tersedia tempat cuci peralatan, tersedia peralatan tempat cuci tangan, dan tersedia tempat sampah. Kemudian tempat menjajakan makanan harus terlindung dari debu dan pencemaran (Kepmenkes, 2003).

Hasil identifikasi bakteri kontaminan pada daging Kebab yang diteliti menunjukkan bahwa 1 sampel yaitu sampel A ditemukan adanya bakteri Salmonella sp. Penelitian Soltan Dalal et al. dalam Kheiry, et al. (2014) menemukan bahwa $17,81 \%$ daging dan daging olahan kemasan dan non-kemasan di Teheran mengandung Salmonella. Ziino, et al. (20113) juga menemukan adanya kontaminasi Salmonella pada daging Kebab. Konsumsi makanan yang mengandung Salmonella dapat menyebabkan Salmonellosis. Penyakit ini adalah salah satu jenis foodborne disease yang paling banyak ditemui di berbagai belahan dunia terutama di daerah berkembang (Kheyri, et al., 2014).

Identifikasi terhadap isolat yang diperoleh yaitu tidak ditemukan $S$. aureus pada seluruh sampel, tetapi ditemukan bakteri yang memiliki karakteristik mirip denngan genus Micrococcus. Menurut Mahon, et. al. (2015), Micrococcus sp sering dijumpai bersamaan dengan $S$. aureus karena keduanya adalah bakteri flora normal pada kulit. Bakteri Micrococcus dapat dibedakan dengan Staphylococcus aureus dengan uji koagulase. Holt, et. al. (2000), menambahkan selain flora normal pada kulit Micrococcus juga umum diisolasi dari produk-produk makanan. Bakteri Micrococcus pada umumnya tidak menyebabkan penyakit tetapi pada kasus tertentu seperti pada pasien yang mengalami gangguan sistem imun, bakteri Micrococcus luteus dapat menginfeksi dan menyebabkan endocarditis, meningitis, dan pneumonia (Engelkirk \& Duben-Engelkirk, 2008).

\section{KESIMPULAN DAN SARAN}

\section{Kesimpulan}

Berdasarkan hasil penghitungan Angka Lempeng Total terhadap 5 sampel daging kebab yang dijual di Jalan Durian Pekanbaru, hanya 1 sampel yang memenuhi syarat dan 4 sampel memiliki nilai ALT melebihi batas maksimum cemaran mikroba pada daging yaitu lebih dari $1 \times 10^{5} \mathrm{CFU} / \mathrm{g}$. Hasil identifikasi menunjukkan bahwa 1 sampel (sampel A) ditemukan positif mengandung Salmonella sp. (isolat SL1) dan pada seluruh sampel tidak ditemukan adanya cemaran Staphylococcus aureus. Empat sampel (A, B, D, E) ditemukan adanya cemaran bakteri yang diduga Micrococcus sp.

\section{Saran}

Untuk menambah data mengenai kualitas mikrobiologis makanan jajanan yang ada di Kota Pekanbaru, disarankan untuk melakukan penelitian lebih lanjut mengenai bakteri lainnya pada kebab dan makanan jajanan lainnya.

\section{DAFTAR PUSTAKA}

Adams, M.R. dan Moss, M.O. 2008. Food Microbiology. RSCPublishing. UK.

Agbodaze, D., Nmai, P.N.A., Robertson, F.C., Yeboah-Manu, D., Owusu-Darko, K., dan Addo, K.K. 2005. Microbiological Quality of "Khebab" Consumed in the Accra Metropolis. Ghana Medical Journal Vol 39 Number 2:46-49.

Engelkirk, P.G. dan Duben-Engelkirk, J. 2008. Laboratory Diagnosis of Infectious Disease: Essentials of Diagnostic Microbiology. Lippincott Williams \& Willkins. Philadelphia.

Hillier, L., Krsteski, R., dan Rockliff, S. 2014. Microbiological Quality of Kebabs and Yeros. ACT Health Protection Service. Australia. [Survey Report].

Hocking, A.D., Pitt, J.I., Samson, R.A., dan Thrane, U. 2006. Advance in Food Mycology. Springer. USA.

Holt, J.G., Krieg, N.R., Sneath, P.H.A., Staley, J.T., dan Williams, S.T. 1994. Bergey's Manual Determinative of Bacteriology: Ninth Edition. Lippincot Williams \& Wilkins. Philadelphia.

Jarallah, E.M., Sahib, S.I., Yasen, K. 2014. Isolation and Identification of Some Pathogenic Bacterial Species Contaminated from Meats in Butchers Shops and Kebab Restaurant in ALKut City. Euphrates Journal of Agriculture Science 6 (4): 30-37. 
Kheyri, A., Fakhernia, M., Haghighat-Afshar, N, Hassanzadazar, H., KazemiGhoshchi, B., Zeynali, F., sadzadeh, J., Rahmanpour, F., Bahmani, M. 2014. Microbial Contamination of Meat Products Produced in the Factories of West Azerbaijan Province, North West of Iran. Global Veterinaria 12 (6): 796-802.

Leboffe, M.J. dan Pierce, B.E. 2011. A Photographic Atlas for the Microbiology Laboratory: $4^{\text {th }}$ Edition. Morton Publishing. Colorado.

Mahon, C.R., Lehan, D.C., dan Manuselis, E. 2015. Textbook of Diagnostic Microbiology: Fifth Edition. Elsevier. Missouri.

Roels, T.H., Frazak, P.A., Kazmierczak, J.J., Mackenzie, W.R., Proctor, M.E., Kurzynski, T.A., dan Davis, J.P. 1997. Incomplete Sanitation of a Meat Grinder and Ingestion of Raw Ground Beef: Contributing Factors to a Large Outbreak of Salmonella Typhimurium Infection. Epidemiol. Infect 119:127134.

Sopandi, T., dan Wardah. 2014. Mikrobiologi Pangan. Andi Offset. Yogyakarta.

Wulandari, E. dan Zubaidah, E. 2016. Kebab Bakso: Inovasi Kuliner Khas Kota Malang Menjadi Modern Sebagai Upaya Pelestarian Kuliner Bangsa. Jurnal Pangan dan Agroindustri Vol.4 No.1: 230-237.

Ziino,G., Gurrera, G., dan Beninati, C. 2013. Microbiological Quality of Kebabs Sold in Palermo and Messina. Italian Journal of Food Safety Vol.2:e23:7780. 